\title{
IMPROVEMENTS OF SOME BOUNDS ON ENTROPY MEASURES IN INFORMATION THEORY
}

\author{
M. Matić, C. E. M. PeArCe AND J. PeČARić
}

Abstract. Recently Dragomir and Goh have produced some interesting new bounds on entropy measures in information theory. We strengthen their results.

Mathematics subject classification (1991): 94A17, $26 \mathrm{D} 15$.

Key words and phrases: Inequalities, bounds, entropy, information.

\section{REFERENCES}

[1] S. S. DRAGOMIR AND C. J. GoH, Some bounds on entropy measures in information theory, Appl. Math. Lett. 10 (3) (1997), 23-28.

[2] R. J. MCELIECE, The theory of information and coding, Addison-Wesley, Reading, Mass., 1977.

[3] D. S. Mitrinović, J. E. PeČARIĆ AND A. M. FinK, Classical and new inequalities in analysis, Kluwer Academ. Publ., Dordrecht, 1993.

[4] J. PeČArić, On an inequality of T. Popoviciu, Bul. Si. Tehn. Inst. Politechn. Timişoara 2, 24 (38) (1979), 9-15. 